\title{
ע Ulkomaalaistaustaisten nuorten seksuaali- ja lisääntymisterveystietämys Kouluterveyskyselyssä 2015
}

Seksuaali- ja lisääntymisterveys (SELl-terveys) on keskeinen osa hyvinvointia ja terveyttä. Ulkomaalaistaustaisten nuorten tietotason ja erityistarpeiden tunteminen on edellytys SELIterveyden edistämiselle ja palvelujen toteuttamiselle tasa-arvoisesti riippumatta asiakkaan kulttuuritaustasta tai kielestä. Tämän tutkimuksen tarkoituksena on selvittää ulkomaalaistaustaisten nuorten SELl-terveystietämyksen tasoa ja verrata sitä suomalaistaustaisten nuorten tietämykseen sekä tarkastella vastaajien taustatekijöiden yhteyttä SELL-terveystietämykseen. Tutkimusaineistona on valtakunnallinen vuonna 2015 toteutettu peruskoulun (I2-19-vuotiaat), lukion (14-20-vuotiaat) ja ammatillisten oppilaitosten opiskelijoille (14-20-vuotiaat) suunnattu Kouluterveyskysely ( $\mathrm{N}=120400$ ). Kyselyn kaksitoista väittämää SELl-terveydestä analysoitiin nuoren ulkomaalaistaustan mukaan. Ulkomaalaistaustaisuus (monikulttuurinen perhe, toisen ja ensimmäisen sukupolven maahanmuuttaja) määriteltiin nuoren oman ja hänen vanhempiensa syntymämaan perusteella. Monikulttuuristen perheiden nuoriin kuuluivat ne nuoret, joiden vanhemmista toinen oli syntynyt Suomessa ja toinen ulkomailla sekä nuoret, jotka olivat itse syntyneet ulkomailla ja joiden vanhemmista toinen oli syntynyt Suomessa ja toisen syntymämaasta puuttui tieto. Nuorista $6,1 \%$ tuli monikulttuurisista perheistä, I,7\% oli toisen ja $3,2 \%$ ensimmäisen sukupolven maahanmuuttajia ja loput suomalaistaustaisia nuoria. Logistisen regression avulla ulkomaalaistaustaisten nuorten tietämystä verrattiin suomalaistaustaisten nuorten tietämykseen ottaen huomioon sukupuoli, kouluaste ja Suomessa asuttu aika. SELl-terveystietämys vaihteli sukupuolen, kouluasteen sekä ulkomaalaistaustan mukaan. Poikien tietämys oli heikompaa kuin tyttöjen ja ulkomaalaistaustaisten nuorten heikompaa kuin suomalaistaustaisten. Lyhyt Suomessa asuttu aika selitti osittain ulkomaalaistaustaisten nuorten heikompaa SELI-tietämystä. Myös Suomessa koko ikänsä asuneiden toisen sukupolven maahanmuuttajataustaisten nuorten tietämystaso oli suomalaistaustaisia nuoria heikompi. Nuoren ulkomaalaistaustalla oli selkeä yhteys SELI-terveystietämystasoon ja yhteys sällyi eri kouluasteilla. Erinomainen SELI-terveystietämys oli kaikissa, myös suomalaistaustaisten, nuorten ryhmissä heikompaa kuin olisi tavoiteltavaa nuorten terveyden ja hyvinvoinnin edistämiseksi.

Asiasanat: Ulkomaalaistaustaisuus, seksuaali- ja lisääntymisterveys, tietämys, nuoret REIJA KLEMETTI, JOHANNA SEPPÄNEN, ANNI MATIKKA, HELJÄ-MARJA SURCEL 


\section{TUTKIMUKSEN TAUSTA}

Kasvaneen maahanmuuton myötä Suomen väestö on monimuotoistunut 2000-luvulta alkaen niin kielellisesti kuin kulttuurisestikin $(1,2)$. Maahanmuuttajien määrä on viime vuosina ollut jopa 30000 muuttajaa vuodessa. Vuonna 2015 Suomessa asui noin 340000 ulkomaalaistaustaista henkilöä syntyperän mukaan luokiteltuna. Heistä ensimmäisen polven maahanmuuttajia oli $84 \%$ ja toisen polven $16 \%$. Vajaa kuusi prosenttia Suomessa asuvista 15-19-vuotiaista oli ulkomaalaistaustaisia.

Seksuaali- ja lisääntymisterveys (SELI-terveys) on keskeinen osa ihmisen terveyttä ja hyvinvointia. Kansainvälisesti katsottuna nuorten SELI-terveys on Suomessa monilla eri mittareilla mitattuna erinomainen. Muun muassa alle 20-vuotiaiden raskauksien ja raskaudenkeskeytysten määrät ovat alhaiset ja yhä vähentyneet 2000-luvulla (3). Toisaalta 20-24-vuotiaiden raskaudenkeskeytysluvuissa ei ole juuri tapahtunut muutosta. Nuorten tietämys seksitaudeilta suojautumisesta on heikkoa eikä esimerkiksi klamydiatartuntojen määrässä ole tapahtunut merkittäviä muutoksia viimeisten viiden vuoden aikana (4-6). Koulussa saatavasta terveystiedon opetuksesta huolimatta nuorten tietämys raskaaksi tulemisesta ja ehkäisystä ei ole edelleenkään riittävällä tasolla, nuorten tiedot seksuaaliterveydestä ovat heikentyneet ja tietämyksen tasossa on selvä ero lukiossa ja ammatillisissa oppilaitoksissa opiskelevien kesken (7).

Ulkomaalaistaustaisten henkilöiden SELI-terveyteen konkreettisesti vaikuttavia tekijöitä ovat muuttosyy, sosioekonominen asema lähtömaassa ja Suomessa, koulutus ja kielitaito, saatu seksuaalikasvatus, ikä, sukupuoli, seksuaalinen suuntautuneisuus ja perhetilanne sekä kulttuurinen ja uskonnollinen tausta $(8,9)$. Riippumatta lähtömaasta tai muista taustatekijöistä, pelkästään muuttaminen maasta toiseen itsessään vaikuttaa ihmisen mahdollisuuksiin huolehtia SELI-terveydestään.

Ulkomaalaistaustaisen nuoren SELI-terveyteen vaikuttavia tekijöitä voivat olla edellä mainittujen lisäksi myös Suomessa asutun ajan pituus, syntymämaa, vanhempien syntymämaat, maahanmuuttoikä sekä mahdollinen pakolaistausta (10). Kulttuuritaustaan pohjautuvat käsitykset terveydestä, sairauksista ja oireiden ilmaisemisesta vaikuttavat ulkomaalaistaustaisten nuorten kokemukseen omasta terveydestä, terveystottumuksiin ja samalla myös terveydenhuoltojärjestelmän kykyyn tunnistaa nuoren tarpeita. SELI-terveys koskettaa elämän intiimejä ja kaikkein yksityisimmiksi asioiksi koettuja terveyden osa-alueita, joiden käsitteleminen vieraalla kielellä vieraassa ympäristössä voi tuottaa vaikeuksia. SELI-terveys on edelleenkin tabu monissa kulttuureissa (11). Lisäksi huono sosioekonominen asema ja heikko koulutustausta (10) voivat heikentää SELI-terveydestä huolehtimista.

Ulkomaalaistaustaisen aikuisväestön SELIterveyttä on tutkittu osana Maahanmuuttajien terveys ja hyvinvointi - sekä Ulkomaalaistaustaisten työ ja hyvinvointi -tutkimuksia $(12,13)$. Ulkomaalaistaustaisten nuorten kokemaa seksuaalisista väkivaltaa on selvitetty Kouluterveyskyselyn avulla vuonna 2013 (10) ja seksuaalikäyttäytymistä Maahanmuuttajataustaisten nuorten terveys- ja hyvinvointitutkimuksessa (14), mutta heidän muusta seksuaaliterveydestään on vain niukasti tietoa (4). Monikulttuurisuuden lisääntymisen myötä ulkomaalaistaustaisten nuorten SELI-terveyteen liittyvät asiat ovat aiempaa ajankohtaisempia Suomessakin ja tarve aiheen tutkimiselle lisääntyy yhä. Tämän tutkimuksen tarkoituksena on tuottaa tietoa ulkomaalaistaustaisten nuorten SELI-terveystietämyksestä ja verrata sitä suomalaistaustaisten nuorten tietämykseen sekä tarkastella vastaajien taustatekijöiden yhteyttä SELI-terveystietämykseen.

\section{AINEISTO JA MENETELMÄT}

Tutkimusaineisto koostuu vuonna 2015 valtakunnalliseen THL:n toteuttamaan Kouluterveyskyselyyn vastanneista peruskoulujen 8. ja 9. luokkien oppilaista sekä lukioiden ja ammatillisten oppilaitosten 1. ja 2. vuoden opiskelijoista. Joka toinen vuosi toteutettavalla Kouluterveyskyselyllä kerätään tietoa nuorten SELI-terveydestä, elinoloista, kouluoloista, terveydestä, terveystottumuksista sekä opiskeluhuollon tuesta. Kysely toteutetaan strukturoidulla kyselylomakkeella oppitunnilla opettajan valvonnassa (15). Kyselyyn vastanneissa on myös erityisluokkien, erityiskoulujen ja ammatillisten erityisoppilaitosten opiskelijoita, jotka ovat pystyneet vastaamaan kyselyyn itsenäisesti.

Opiskelijoiden SELI-terveystietämyksen tasoa mitattiin opetussisältöjä koskevien väittämien avulla. Väittämät ("oikein”, "väärin” tai "en tiedä") olivat seuraavat: 
1. Kuukautisten alkaminen on merkki siitä, että tyttö voi tulla raskaaksi.

2. Nainen ei voi tulla raskaaksi ensimmäisellä yhdyntäkerralla.

3. Naisen tuleminen raskaaksi vaikeutuu yleensä noin 35 ikävuoden kohdalla

4. Siemensyöksyjen alkaminen on merkki siitä, että poika on tullut sukukypsäksi ja voi tulla isäksi.

5. Kondomin ostolle ei ole ikärajaa.

6. Ehkäisyvälineistä vain kondomi suojaa seksitaudeilta.

7. Seksitauti- tai hiv-tartunta voi olla täysin oireeton.

8. Klamydiatulehdus voi aiheuttaa hedelmättömyyttä.

9. Kerran sairastettua seksitautia ei voi saada uudestaan.

10. Hiv jää tartunnan jälkeen pysyvästi elimistöön.

11. Papillooma (HPV) -rokote suojaa kohdunkaulan syövältä.

12. Papillooma (HPV) -rokote suojaa kaikilta seksitaudeilta.

Oikeita vastauksia tarkasteltiin väittämä väittämältä kouluasteen, sukupuolen ja ulkomaalaistaustaisuuden mukaan. Nuoren tietämys määriteltiin erinomaiseksi, jos hän tiesi jokaisen väittämän kohdalla, oliko väittämä väärin vai oikein.

Vuoden 2015 Kouluterveyskysely mahdollisti ulkomaalaistaustaisten nuorten terveystutkimuksen, koska kyselyyn oli sisällytetty kysymys vastaajien ja heidän vanhempiensa syntymämaasta. Ensimmäisen kerran kysymys oli vuoden 2013 Kouluterveyskyselyssä (10). Vastausvaihtoehtoina olivat Suomi, Ruotsi, Venäjä, Viro, muu Euroopan maa, Somalia, Irak, Kiina, Thaimaa tai jokin muu maa.

Nuoren ulkomaalaistaustaisuus luokiteltiin nuoren ja vanhempien syntymämaan mukaan seuraavasti: suomalaistaustainen nuori, monikulttuurisen perheen nuori, toisen polven maahanmuuttaja ja ensimmäisen polven maahanmuuttaja. Suomalaistaustaisiin kuuluivat Suomessa syntyneiden vanhempien nuoret. Monikulttuuristen perheiden nuoriin kuuluivat ne nuoret, joiden vanhemmista toinen oli syntynyt Suomessa ja toinen ulkomailla. Lisäksi tähän luokkaan kuuluivat nuoret, jotka olivat itse syn- tyneet ulkomailla ja joiden vanhemmista toinen oli syntynyt Suomessa ja toisen syntymämaasta puuttui tieto. Toisen polven maahanmuuttajiksi määriteltiin nuoret, jotka itse olivat syntyneet Suomessa mutta molemmat tai ainoa vanhempi muualla. Ensimmäisen polven maahanmuuttajiksi määriteltiin puolestaan nuoret, jotka olivat syntyneet muualla ja joiden molemmat tai ainoa vanhempi oli syntynyt muualla. Käyttämämme luokitus poikkeaa hieman Tilastokeskuksen (2) luokituksesta, jossa niin sanottujen kaksikulttuuristen perheiden lapsia ei luokitella ulkomaalaistaustaisiksi. Kouluterveyskyselyä analysoitaessa on kuitenkin havaittu, että näiden perheiden nuoret eroavat hieman suomalaistaustaisista nuorista (10), joten heidät on haluttu pitää omana ryhmänä tässäkin analyysissä.

Katoanalyysin mukaan suurimman osan kadosta muodostivat kyselypäivänä koulusta poissa olleet nuoret. Lisäksi vaatimus itsenäisestä vastaamisesta karsi pois osan vammaisista tai avustamista tarvitsevista nuorista sekä ne ulkomaalaistaustaiset nuoret, jotka eivät osanneet riittävän hyvin suomea tai ruotsia. Lopullisesta aineistosta poistettiin niiden nuorten vastaukset, jotka olivat vastanneet alle puoleen kysymyksistä ( $n=1737)$, eivät olleet ilmoittaneet sukupuoltaan $(\mathrm{n}=989)$ tai luokka-astettaan $(\mathrm{n}=574)$. Tutkimuksen ikärajauksen vuoksi lukion ja ammatillisten oppilaitosten aineistosta poistettiin 3. vuoden opiskelijoiden vastaukset $(\mathrm{n}=2052)$. Ammattiin opiskelevien aineisto rajattiin alle 21-vuotiaisiin, minkä vuoksi poistettiin vielä 6987 opiskelijan vastaukset.

Aineisto analysoitiin käyttämällä SPSS-tilastoohjelman versiota 22. Luokiteltujen muuttujien analysoimisessa käytettiin ristiintaulukointia. Oikeiden vastausten keskiarvot ja keskihajonnat laskettiin ulkomaalaistaustaisuuden mukaan. Logistisessa regressioanalyysissä verrattiin eri ulkomaalaistaustaisten ryhmien nuorten tietämystä suomalaistaustaisten nuorten tietämykseen ja tyttöjen tietämystä poikien tietämykseen eri kouluasteilla. Tietämyksen indikaattorina käytettiin erinomaista tietämystä eli sitä, että nuori oli tiennyt kaikkiin väittämiin oikean vastauksen. Regressioanalyysi tehtiin sekä ilman vakiointia että vakioiden Suomessa asuttu aika vuosina (koko iän Suomessa asuneet, yli 10 vuotta asuneet, 5-10 vuotta asuneet, 1-4 vuotta asuneet ja alle vuoden asuneet), sukupuoli ja 
kouluaste. Aiemman, vuoden 2013 aineiston perusteella Suomessa asuttu aika selitti eri ryhmien eroja ja siksi se haluttiin ottaa huomioon lopullisessa mallissa (19). Perheen sosioekonomista asemaa ei otettu malliin mukaan, koska se on nuorten itsensä ilmoittama ja siten suhteellisen epäluotettava. Analyysi tehtiin myös jättämällä pois alle vuoden Suomessa asuneet nuoret. Sen lisäksi tehtiin analyysit erikseen 1-4 vuotta ja 5-10 vuotta Suomessa asuneille.

Kouluterveyskyselyn tutkimussuunnitelma on arvioitu THL:n eettisessä toimikunnassa (6.11.2014).

\section{TUTKIMUSTULOKSET}

Vastaajina oli yhteensä 120400 nuorta, joista $42 \%$ oli peruskoululaisia (14-19-vuotiaita), 32\% lukiolaisia (14-20-vuotiaita) ja 26\% ammatillisissa oppilaitoksissa opiskelevia (14-20-vuotiaita) (Taulukko 1). Vastausprosentti oli 43 peruskouluissa ja 64 lukioissa. Ammatillisissa oppilaitoksissa vastausprosenttia ei voitu laskea tarkasti, koska opiskelijamääriä ei kerätä valtakunnallisesti vuosikursseittain.

Nuorista 87,6 \% oli suomalaistaustaisia nuoria: lukiossa osuus oli suurin ja peruskoulussa pienin (Taulukko 1). Kaiken kaikkiaan $6,1 \%$ oli monikulttuuristen perheiden nuoria, $1,7 \%$ toisen ja 3,2\% ensimmäisen polven maahanmuuttajanuoria. Osuudet olivat hyvin samanlaisia eri kouluasteilla, lukuun ottamatta lukiota, missä ensimmäisen polven maahanmuuttajia oli selvästi vähemmän kuin peruskoulussa tai ammatillisissa oppilaitoksissa. Ulkomaalaistaustaisista nuorista yli puolet $(55 \%)$ oli monikulttuuristen perheiden nuoria, noin kolmannes $(29 \%)$ oli toisen polven maahanmuuttajia ja $16 \%$ ensimmäisen polven maahanmuuttajia.

Kaikista vastaajista tyttöjä oli hiukan enemmän kuin poikia (51,5 vrt. 48,5\%). Poikkeuksena olivat peruskoulussa ja ammatillisissa oppilaitoksissa opiskelevat ensimmäisen polven maahanmuuttajanuoret sekä ammatillisissa oppilaitoksissa opiskelevat suomalaistaustaiset nuoret, joissa poikia oli selvästi enemmän kuin tyttöjä.

Peruskoulussa opiskelevien poikien suurin ulkomaalaistaustaisten ryhmä olivat Somaliassa syntyneet ja tyttöjen muualta Euroopasta lähtöisin olevat nuoret (Taulukko 1). Lukiossa sekä tyttöjen että poikien suurimmat ryhmät olivat muualla Euroopassa syntyneet nuoret. Amma- tillisissa oppilaitoksissa opiskelevien suurimmat tyttöjen ja poikien ryhmät olivat Venäjällä syntyneitä nuoria.

Kaikista vastaajista yli $91,5 \%$ oli asunut Suomessa koko ikänsä: 96,2\% suomalaistaustaisista nuorista, 79,0\% monikulttuuristen perheiden nuorista ja 92,7\% toisen polven maahanmuuttajista. Vähän aikaa Suomessa asuneita oli erityisesti ensimmäisen polven maahanmuuttajanuorissa, joista $21 \%$ oli asunut Suomessa alle vuoden. Vastaava luku oli monikulttuuristen perheiden nuorilla vain vajaa prosentti ja toisen polven maahanmuuttajilla yksi prosentti.

Kaikilla kouluasteilla ja eri ulkomaalaistaustaisten nuorten ryhmissä tiedettiin parhaiten vastaus siemensyöksyä koskevaan väittämään (Liitetaulukko). Ainoa poikkeus olivat monikulttuuristen perheiden nuoret lukiossa. He tiesivät parhaiten sen, että nainen voi tulla raskaaksi ensimmäisellä yhdyntäkerralla. Peruskoulussa ja ammatillisessa oppilaitoksessa toiseksi parhaiten tiedettiin, että kondomin ostolle ei ole ikärajaa. Lukiossa tunnettiin hyvin kuukautisiin ja raskaaksi tulemiseen liittyvät väittämät. Suomalaistaustaisten ja monikulttuuristen perheiden nuoret tunsivat hyvin myös kondomin seksitaudeilta suojaavan vaikutuksen.

Huonosti tiedettiin klamydiatulehduksen aiheuttavan hedelmättömyyttä (väittämä 8), erityisesti peruskoulussa, jossa "En tiedä" - vastanneita oli kaikissa ryhmissä yli $45 \%$. Lukiossakin vain $67 \%$ suomalaistaustaisista nuorista ja $46 \%$ ensimmäisen ja toisen polven maahanmuuttajista vastasi oikein väittämään (Liitetaulukko). Ammatillisissa oppilaitoksissa suomalaistaustaiset ja ensimmäisen polven maahanmuuttajanuoret tiesivät huonoiten HPV-rokotteen suojaavan vaikutuksen (väittämä 11). HPV- rokotteeseen liittyviin väittämiin $(11,12)$ saatiin muita väittämiä heikommat tulokset kaikilla kouluasteilla riippumatta ulkomaalaistaustaisuudesta. Tietämys seksitaudeista parani selvästi lukioa tai ammatillista oppilaitosta käyvien nuorten keskuudessa. Kondomin suojaava vaikutus ja seksitautien mahdollinen oireettomuus oli huonoimmin tunnettu toisen ja ensimmäisen polven maahanmuuttajien keskuudessa.

Peruskoululaisten tietämys naisen iän vaikutuksesta mahdollisuuteen tulla raskaaksi (väittämä 3) vaihteli ensimmäisen polven maahanmuuttajien 44 prosentista suomalaistaustaisten 







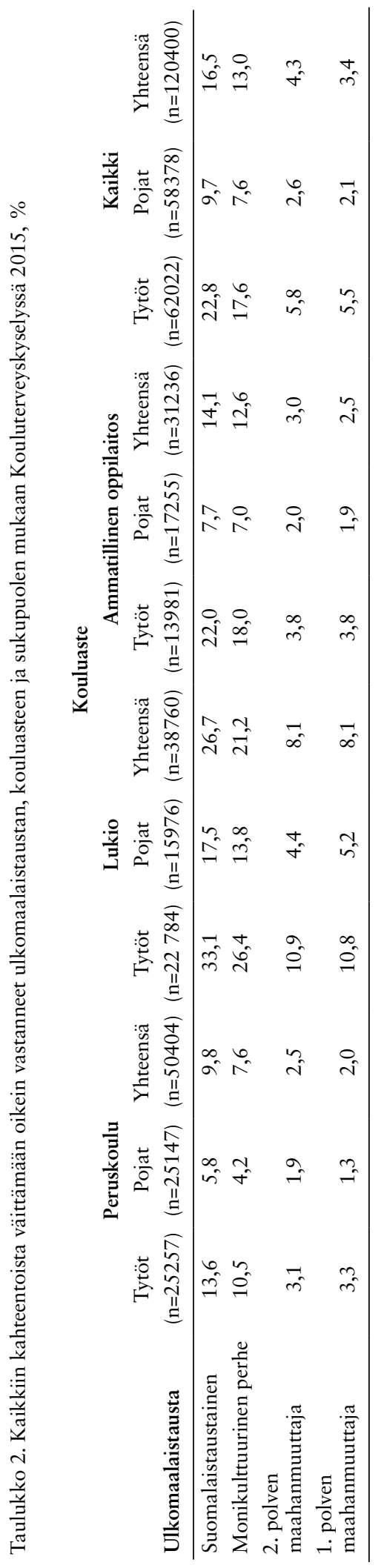

nuorten 62 prosenttiin (Liitetaulukko). Lukiossa vastaava vaihtelu oli $64-79 \%$ ja ammatillisissa oppilaitoksissa $51-68 \%$.

Nuorten ulkomaalaistaustan mukaan tarkasteltuna paras SELI-tietämys oli suomalaistaustaisilla nuorilla. Oikeiden vastausten keskiarvo vaihteli heillä peruskoulun 8,3:sta lukion 10,0:aan. Vastaava vaihtelu oli monikulttuuristen perheiden nuorilla hyvin samankaltainen: 7,9-9,6. Toisen ja ensimmäisen polven maahanmuuttajilla keskiarvot olivat jo selvästi huonommat: vaihtelu 6,4-8,0 ja 5,5-7,5. Ammatillisissa oppilaitoksissa opiskelevien keskiarvot sijoittuivat peruskoululaisten ja lukiolaisten keskiarvojen välille. Tarkasteltaessa tietämystä oikeina vastauksina kaikkiin väittämiin suomalaistaustaisista nuorista $17 \%$ tiesi oikean vastauksen kaikkiin väittämiin (Taulukko 2). Monikulttuuristen perheiden nuorista hieman harvemmalla oli erinomaiset tiedot. Toisen ja ensimmäisen polven maahanmuuttajilla ei juuri ollut eroa; 3-4 \% tiesi oikean vastauksen kaikkiin väittämiin. Suomalaistaustaisista lukiolaisnuorista vajaa kolmannes tiesi oikean vastauksen kaikkiin väittämiin. Toiseksi parhaiten pärjäsivät ammatillisessa oppilaitoksessa opiskelevat. Eri kouluasteiden ero näkyi niin suomalaistaustaisilla kuin kaikilla ulkomaalaistaustaisten ryhmillä. Vakioitaessa Suomessa asuttu aika tulokset muuttuivat hieman: heikoin tietämys oli toisen polven maahanmuuttajanuorilla, mikä näkyi kaikilla kouluasteilla (Taulukko 3). Kun alle vuoden Suomessa asuneet jätettiin pois analyysistä, tulokset eivät juuri muuttuneet. 5-10 vuotta Suomessa asuneet tiesivät oikean vastauksen kaikkiin väittämiin hieman todennäköisemmin kuin 1-4 vuotta Suomessa asuneet, mutta tulokset eivät muuttuneet tilastollisesti merkittävästi.

Tyttöjen tietämys oli pääosin parempi kuin poikien (Liitetaulukko). Poikkeuksena olivat lukiossa suomalaistaustaisten ja monikulttuuristen perheiden poikien hieman parempi tietämys kondomin oston ikärajattomuudesta, ammatillisissa oppilaitoksissa opiskelevien toisen polven maahanmuuttajapoikien tietämys hiv-infektiosta ja peruskoulun ensimmäisen polven maahanmuuttajapoikien tietämys klamydiainfektion hedelmällisyyttä alentavasta vaikutuksesta, seksitautien mahdollisesta oireettomuudesta ja hiv-infektiosta. 
Taulukko 3. Ulkomaalaistaustaisten nuorten SELI-tietämys ${ }^{1}$ valtaväestön nuoriin verrattuna $\left(\mathrm{OR}^{2}\right.$ ja $95 \%$ luottamusväli) kouluasteen ja sukupuolen mukaan Kouluterveyskyselyssä 2015

\begin{tabular}{|c|c|c|c|c|c|c|}
\hline \multirow{3}{*}{$\frac{\text { Kouluaste }}{\text { Peruskoulu }}$} & \multicolumn{6}{|c|}{ Sukupuoli } \\
\hline & \multicolumn{2}{|c|}{$\begin{array}{c}\text { Tytöt } \\
(\mathrm{n}=62022)\end{array}$} & \multicolumn{2}{|c|}{$\begin{array}{c}\text { Pojat } \\
(\mathrm{n}=58378)\end{array}$} & \multicolumn{2}{|c|}{$\begin{array}{c}\text { Yhteensä } \\
(\mathrm{n}=120400)\end{array}$} \\
\hline & OR & $95 \% \mathrm{CI}$ & OR & $95 \% \mathrm{Ci}$ & OR & $95 \%$ \\
\hline Suomalaistaustainen & 1 & & 1 & & 1 & \\
\hline Monikulttuurinen perhe & 0,81 & $0,69-0,94$ & 0,76 & $0,59-0,99$ & 0,79 & $0,69-0,91$ \\
\hline $\begin{array}{l}\text { Toisen polven } \\
\text { maahanmuuttaja }\end{array}$ & 0,21 & $0,13-0,34$ & 0,33 & $0,17-0,64$ & 0,24 & $0,16-0,35$ \\
\hline $\begin{array}{l}\text { Ensimmäisen polven } \\
\text { maahanmuuttaja }\end{array}$ & 0,39 & $0,24-0,63$ & 0,34 & $0,19-0,61$ & 0,37 & $0,25-0,53$ \\
\hline \multicolumn{7}{|l|}{ Lukio } \\
\hline Suomalaistaustainen & 1 & & 1 & & 1 & \\
\hline Monikulttuurinen perhe & 0,76 & $0,67-0,86$ & 0,79 & $0,65-0,96$ & 0,77 & $0,69-0,85$ \\
\hline $\begin{array}{l}\text { Toisen polven } \\
\text { maahanmuuttaja }\end{array}$ & 0,25 & $0,18-0,34$ & 0,22 & $0,12-0,39$ & 0,24 & $0,18-0,32$ \\
\hline $\begin{array}{l}\text { Ensimmäisen polven } \\
\text { maahanmuuttaja }\end{array}$ & 0,35 & $0,25-0,50$ & 0,34 & $0,21-0,55$ & 0,35 & $0,26-0,46$ \\
\hline \multicolumn{7}{|l|}{ Ammatillinen oppilaitos } \\
\hline Suomalaistaustainen & 1 & & 1 & & 1 & \\
\hline Monikulttuurinen perhe & 0,81 & $0,67-0,97$ & 0,98 & $0,74-1,30$ & 0,86 & $0,74-1,00$ \\
\hline $\begin{array}{l}\text { Toisen polven } \\
\text { maahanmuuttaja }\end{array}$ & 0,14 & $0,07-0,29$ & 0,26 & $0,10-0,71$ & 0,17 & $0,10-0,30$ \\
\hline $\begin{array}{l}\text { Ensimmäisen polven } \\
\text { maahanmuuttaja }\end{array}$ & 0,19 & $0,10-0,36$ & 0,45 & $0,24-0,83$ & 0,28 & $0,18-0,44$ \\
\hline
\end{tabular}

${ }^{1}$ SELI-tietämys = kaikkiin kahteentoista seksuaali- ja lisääntymisterveyttä koskevaan väittämään oiken vastanneet ${ }^{2}$ Vakioituna Suomessa asuttu aika vuosina

Tyttöjen parempi tietämys kokonaisuudessaan tuli erityisen selkeäksi, kun tarkasteltiin kaikkiin kysymyksiin oikein vastanneita (Taulukko 2). Tämä näkyi eri kouluasteilla ja kaikissa ulkomaalaistaustaisten nuorten ryhmissä ja säilyi vakioitaessa Suomessa asuttu aika ja ulkomaalaistaustaisuus lukuun ottamatta ensimmäisen polven maahanmuuttajia peruskouluissa ja ammatillisissa oppilaitoksissa (Taulukko 4). Heillä ero ei ollut enää vakioinnin jälkeen tilastollisesti merkitsevä.

\section{POHDINTA JA JOHTOPÄÄTÖKSET}

\section{YHTEENVETO}

Nuorten SELI-terveystietämys vaihteli sukupuolen, kouluasteen ja ulkomaalaistaustaisuuden mukaan. Tyttöjen tietämys oli parempi kuin poikien, lukiolaisten parempi kuin peruskoululaisten ja suomalaistaustaisten parempi kuin muiden nuorten. Toisen polven maahanmuuttajanuorten tietämystaso oli suomalaistaustaisia heikompi ja ensimmäisen polven maahanmuuttajien tietämys heikompi kuin toisen polven. Suomessa asuttu aika vakioituna ensimmäisen polven maahanmuuttajien tietämys oli kuitenkin kokonaisuudessaan parempi kuin toisen polven tietämys. 
Taulukko 4. Tyttöjen SELI-tietämys ${ }^{1}$ verrattuna poikien tietämykseen $\left(\mathrm{OR}^{2}, 95 \%\right.$ luottamusväli)

ulkomaalaistaustan ja kouluasteen mukaan Kouluterveyskyselyssä 2015

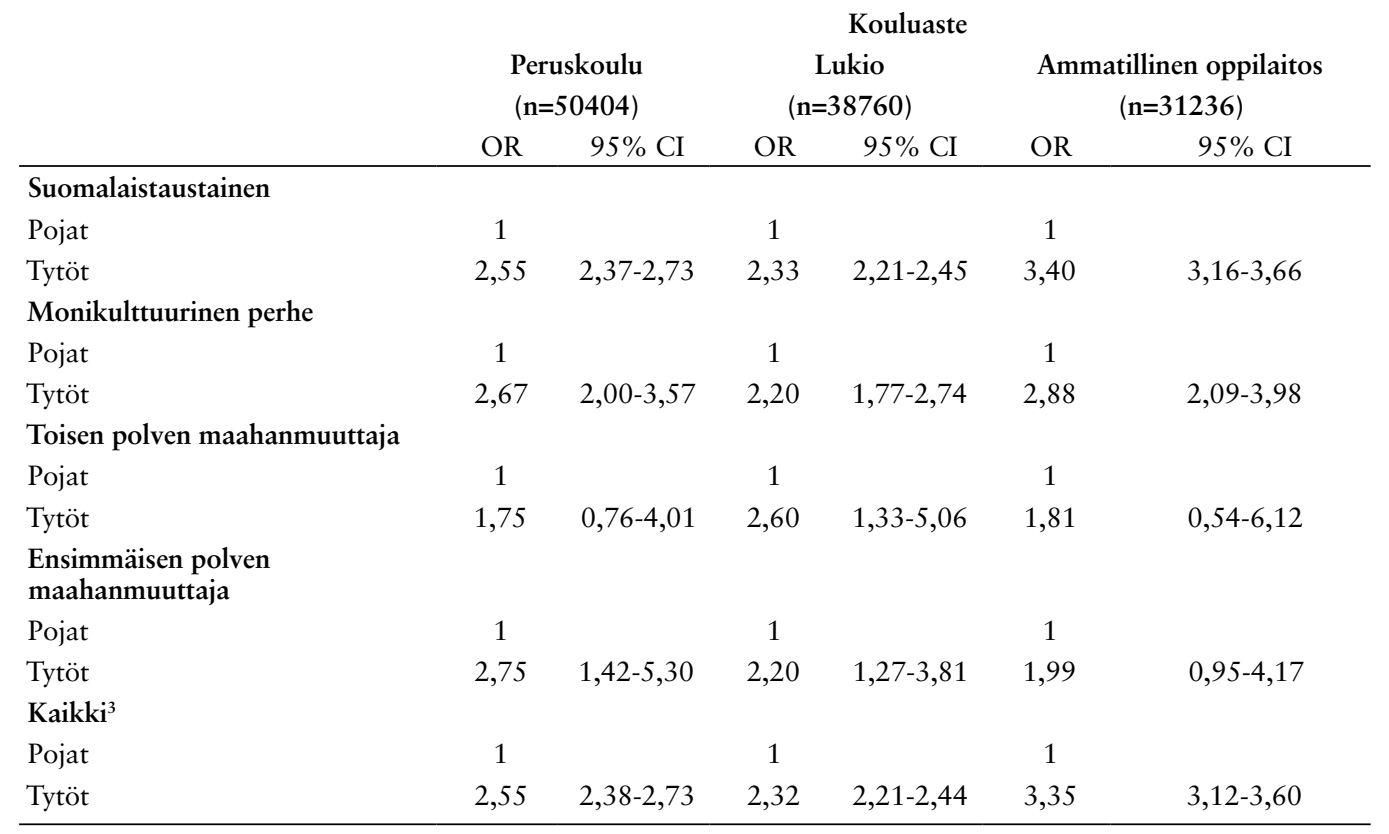

${ }^{1}$ SELI-tietämys = kaikkiin kahteentoista seksuaali- ja lisääntymisterveyttä koskevaan väittämään oiken vastanneet

${ }^{2}$ Vakioitu Suomessa asuttu aika vuosina

${ }^{3}$ Vakioitu myös ulkomaalaistausta

\section{VAHVUUDET JA HEIKKOUDET}

Tutkimuksen vahvuus on se, että se perustuu kattavaan kansalliseen kyselytutkimukseen, johon vastanneiden määrä on huomattava ja joka järjestetään valtakunnallisesti samaan aikaan vuodesta mahdollisuuksien mukaan kaikille vastaajille samanlaisissa olosuhteissa, valvotussa luokkatilassa ja hyvän ohjeistuksen saaneena (15). Kysymykset on esitestattu ja niiden on todettu olevan selkeitä ja ymmärrettäviä. Kysymyksiä ei esitestattu kohdennetusti ulkomaalaistaustaisilla nuorilla, mutta heitä oli luokissa, joissa testaus tehtiin. SELI-väittämien aiheet ovat jo pitkään sisältyneet peruskoulun 8.-9. -luokkalaisten opetussuunnitelmaan ja oppilaiden voisi ajatella osaavan vastata väittämiin (16).

Sosioekonomisella taustalla on yhteys henkilön SELI-terveyteen (17). Vanhemman koulutuksella voisi siten olla merkitystä myös nuorten SELI-tietämykseen. Tutkimuksen heikkoutena on se, että aineisto ei mahdollista täysin luotetta- vasti vanhempien sosioekonomisen taustan vaikutuksen selvittämistä nuoren tietämystasoon. Toisaalta tuloksia on tarkasteltu nuoren oman koulutason mukaisesti.

Toinen tutkimuksen heikkous liittyy siihen, että tutkimus toteutettiin ensimmäisen kerran pääosin sähköisenä ja tiedonkeruussa esiintyi ajoittain palvelinympäristön liiallisesta kuormituksesta johtuvia ongelmia, kuten vastaamisen hitautta, keskeytymistä tai estymistä. Ongelmien takia sähköinen tiedonkeruu keskeytettiin aiottua aiemmin ja vastaajien määrä jäi tavanomaista pienemmäksi. Aineiston luotettavuutta selvitettiin perusteellisesti katoanalyyseillä tarkastelemalla puuttuvia tietoja sekä muuttujaettä vastaajakohtaisesti. Puuttuvien tietojen samanaikaisessa esiintymisessä ei ollut systemaattisuutta eikä alueittaisia tai sukupuolittaisia eroja eikä yhteyttä vastaamiseen käytettyyn aikaan, vastaamiseen liittyviin ongelmiin eikä vastausaktiivisuuteen. Eroja ei ollut keskeisten 
muuttujien jakaumissa sen suhteen, oliko koululla tai oppilaitoksella ollut ongelmia vastaamisessa. Muuttujien keskiarvot eivät myöskään olleet riippuvaisia vastausaktiivisuudesta. Sähköisen vastaamisen ongelmat eivät siis oleellisesti vaikuttaneet koko maasta raportoitavan tiedon laatuun, vaan tietoja voidaan sähköisen tiedonkeruun ongelmista huolimatta pitää katoanalyysien perusteella kansallisesti yleistettävinä. Näin ollen ei ole oletettavaa, että tavallista alhaisempi kattavuus olisi vaikuttanut erityisesti kyselyyn vastanneiden ulkomaalaistaustaisten nuorten määrään tai heidän vastaustensa luotettavuuteen.

Vaikka vastaajia oli tavanomaista vähemmän, ulkomaalaistaustaisia oli prosentuaalisesti yhtä paljon kuin vuonna 2013 (11\% vuonna 2015 ja $10 \%$ vuonna 2013). Kaikista vastaajista ulkomaalaistaustaisia nuoria oli yhteensä 13330 eli riittävästi tutkimuksen toteuttamiseksi. Tutkimus ei kuitenkaan tavoittanut niitä nuoria, jotka eivät osanneet suomea tai ruotsia niin hyvin, että olisivat voineet vastata kyselyyn. Riittävän kielitaidon arvioiminen perustui pääosin oppilaan omaan arvioon. Joitakin oppilaita opettaja on saattanut ohjeistaa, mutta tästä ei ole varmaa tietoa. Mielenkiintoista oli, että kyselyyn vastanneista ensimmäisen polven maahanmuuttajanuorista viidennes oli ollut Suomessa vajaan vuoden ja silti pystyi vastaamaan kyselyyn. Kaikki eivät ehkä ole ymmärtäneet väittämiä, joten vastaukset eivät välttämättä ole täysin luotettavia.

Kolmas tutkimuksen heikkous on se, että ammatillisen oppilaitoksen opiskelijoiden vastausprosenttia ei voitu laskea tarkasti, koska siellä opiskelijamääriä ei kerätä valtakunnallisesti vuosittain toisin kuin peruskoulussa ja lukiossa (15). Toisaalta tutkimuksen rikkaus on siinä, että tietoa ulkomaalaistaustaisten nuorten SELItietämyksestä saatiin kolmelta kouluasteelta.

\section{TULOSTEN TARKASTELUA}

Tyttöjen SELI-tietämys oli poikia parempi. Näin oli myös englantilaisessa tutkimuksessa (18). Suomalaista tieteellistä tutkimusta aiheesta ei ole ollut, mutta Kouluterveyskyselyn (7) ja opinnäytetyön (19) perusteella siitä on aiemmin saatu viitteitä. Selvitettäessä suomalaisten yliopistoopiskelijoiden tietämystä hedelmällisyydestä, raskaaksi tulemisesta ja iän vaikutuksesta raskauden riskeihin naisopiskelijat tiesivät vastaukset selvästi miesopiskelijoita paremmin $(20,21)$.
Tämän tutkimuksen mukaan pojat tiesivät joihinkin väittämiin vastaukset tyttöjä paremmin. Näin oli erityisesti ulkomaalaistaustaisten nuorten kohdalla. Monikulttuuristen perheiden lukiolaispojat tiesivät tyttöjä paremmin sen, että kondomin ostolle ei ole ikärajaa, ammatillisen oppilaitoksen toisen polven maahanmuuttajapoikien hiv-infektiotietämys oli tyttöjä parempi ja peruskoulun ensimmäisen polven maahanmuuttajapojat tiesivät tyttöjä enemmän seksitaudeista. Erot voivat selittyä ulkomaalaistaustaisten nuorten kulttuurien erilaisilla käsityksillä muun muassa seurustelusta ja avioliitosta, esiaviollisista suhteista, sukupuolirooleista, mieheydestä ja naiseudesta (4,22-24). Ulkomaalaistaustaisilla nuorilla voi olla puutteelliset tiedot lisääntymisanatomiasta ja fysiologiasta, sillä monissa kulttuureissa seksuaalisuutta käsittelevää tietoa pidetään haitallisena eikä sitä siksi käsitellä ollenkaan $(8,25)$. Poikien seksikäyttäytymistä kontrolloidaan yleensä vähemmän kuin tyttöjen (26) ja tyttöjä suojellaan kaikin tavoin poikia enemmän (23), joten voi olla, että pojilla on ollut tyttöjä parempi mahdollisuus ja suurempi motivaatio ja tarve hankkia tietoa juuri näistä SELI-tietämyksen osa-alueista.

Kokonaisuutena tyttöjen tietämys oli kuitenkin poikia parempaa. Yleistä kouluttautumista tai koulumenestystä mittaavien suomalaistutkimusten mukaan ulkomaalaistaustaisten tyttöjen sekä koulumenestys (23) että kouluttautuminen ylipäänsä on Suomessa ollut maahanmuuttajataustaisia poikia parempi (27). Tutkittaessa Suomessa asuvia somali- ja kurditaustaisia nuoria havaittiin, että parhain koulumenestys oli somalitaustaisilla tytöillä (28).

Toisen polven maahanmuuttajilla peruskouluissa ja ammatillisissa oppilaitoksissa sekä ensimmäisen polven maahanmuuttajilla ammatillisissa oppilaitoksissa tyttöjen ja poikien ero ei vakioinnin jälkeen ollut tilastollisesti merkitsevä. Tämä voi viitata juuri tuohon aiemmin mainittuun perustiedon puutteeseen ja kulttuuriseen vaikenemiseen vaikeana tai tabuna pidetystä asiasta - tieto puuttuu sekä tytöiltä että pojilta. Se voi myös liittyä siihen, että kriteerinä erinomaisille tiedoille pidimme sitä, että nuori oli osannut vastata kaikkiin kysymyksiin oikein. Löysemmillä kriteereillä erinomaisesti tietäneitä olisi ollut enemmän ja vertailu siksi ehkä luotettavampaa. Toisaalta väittämät ovat nuorten 
seksuaali- ja lisääntymisterveyden kannalta niin merkittävä, että tavoitteena tulisi olla kaikkien kyseisten asioiden tietäminen.

Tyttöjen ja poikien tietämyksessä oli erityisen suuri ero HPV (human papilloma virus) -rokotetta koskevissa väittämissä. Tyttöjen selvästi parempaa tietämystä HPV-väitteiden osalta voi selittää se, HPV-rokote tuli kansalliseen rokoteohjelmaan Suomessa vuonna 2013 koskien 11-12-vuotiaita tyttöjä (29). Ohjelman kahtena ensimmäisenä vuonna rokotteen saavat myös 7.9. luokkalaiset eli 13-15-vuotiaat tytöt. Ennen rokottamisten aloittamista THL järjesti tiedotustilaisuuden HPV-rokotteesta, lähetti kirjeitse tietoa HPV-rokotuksista kaikille rokotusohjelmaan kuuluville tytöille ja heidän vanhemmilleen sekä perusti nettisivun aiheesta (30).

Lukiolaisten ja ammatillisissa oppilaitoksissa opiskelevien tietämys oli parempi kuin peruskoululaisten. Tämä näkyi myös kaikissa ulkomaalaistaustaisten nuorten ryhmissä. Koulussa opitut asiat sekä iän ja kokemuksen karttuminen selittävät osittain näitä tuloksia. Peruskoulun yläluokilla terveystietoa opetetaan omana oppiaineenaan kolme vuosiviikkotuntia (31). Lukion opetussuunnitelmassa terveystietoa on yksi pakollinen sekä kaksi valinnaista kurssia (32). Sekä peruskoulun että lukion opetussuunnitelmissa mainitaan erikseen seksuaaliterveyteen liittyviä aiheita $(32,33)$. Lukiossa syvennetään sitä, mitä peruskoulussa on opetettu. Ammatillisen perustutkinnon opetussuunnitelman mukaan terveystietoa on yksi opintoviikko, joka vastaa noin 40 tunnin työpanosta (34). Lukiolaisilla voi siis ajatella jo kouluopetuksen perusteella olevan muita paremmat valmiudet vastata SELI-tietämystä mittaaviin kysymyksin.

Yllä mainitut tulokset liittyvät myös laajemmin siihen, että sosioekonomisella taustalla on yhteys henkilön SELI-terveyteen (17), vanhempien sosioekonomisella asemalla lasten terveydentilaan (35) ja vanhempien työmarkkina-asemalla eri etnisiin ryhmiin kuuluvien toisen sukupolven nuorten koulumenestykseen $(23,36,37)$. Vanhempien korkeammalla koulutuksella ei ollut ulkomaalaistaustaisten nuorten koulumenestykselle samanlaista merkitystä kuin suomalaistaustaustaisten nuorten vanhempien koulutuksella $(23,36)$. Suurempi merkitys oli vanhempien työmarkkina-asemalla ja tuloilla kuin heidän koulutuksellaan. Opintojen jatkaminen lukiossa oli kuitenkin huomattavasti todennäköisempää ulkomaalaistaustaisten nuorten keskuudessa, kun otettiin huomioon valintaa selittävät tekijät, kuten vanhempien resurssit ja aikaisempi koulumenestys. Ulkomaalaistaustaiset vanhemmat osallistuvat nuorten koulutusvalintoihin huomattavasti suomalaissyntyisiä vanhempia enemmän. Näiden nuorten tulevaisuudensuunnitelmat olivat usein pidemmälle kehittyneitä kuin suomalaistaustaisten nuorten. Lukioon pyrkivien keskuudessa maahanmuuttajataustaisilla nuorilla oli selkeämmät urasuunnitelmat kuin suomalaistaustaisilla nuorilla. Näin ollen lukioon on jo valikoitunut nuoria, joilla voi ajatella olevan motivaatiota uuden oppimiseen ja omaksumiseen.

Monikulttuuristen perheiden nuorten SELItietämys oli monien väittämien kohdalla hyvin lähellä suomalaistaustaisten nuorten tietämystä, mutta toisen polven maahanmuuttajien tietämys oli jo selvästi heikompi. Lyhyt Suomessa asuttu aika ja siihen mahdollisesti liittyvä heikko kielitaito selittävät ensimmäisen polven maahanmuuttajanuorten heikkoa tietämystä. Viidennes oli asunut Suomessa vajaan vuoden. Toisaalta heidän poisjättäminen analyysistä ei oleellisesti muuttanut tuloksia. Sen sijaan paremmin tiesivät ne nuoret, jotka olivat asuneet Suomessa pidempään kuin neljä vuotta. Toisen ja ensimmäisen polven maahanmuuttajien tietämyksessä ei ollut kovin suuria eroja. Kun Suomessa oloaika otettiin huomioon, ensimmäisen polven maahanmuuttajien tietämys oli jopa parempi kuin toisen polven. Nuoren oma tai vanhempien lähtömaa voi selittää tätä: ensimmäisen polven maahanmuuttajissa oli enemmän muualta Euroopasta ja Venäjältä tulleita, kun taas toisen polven maahanmuuttajissa oli enemmän somalija aasialaistaustaisia nuoria, joiden tilanne on lähtökohdiltaan (12), myös seksuaaliterveyden ja -tietämyksen kannalta erilainen kuin Euroopasta (38) tai Venäjältä tulleiden.

Ihmisen lisääntymisterveyteen liittyvät kysymykset ja kondomin seksitaudeilta suojaava vaikutus olivat parhaiten tunnettuja asioita eri kouluasteilla kaikissa ulkomaalaistaustaisten nuorten ryhmissä. Sen sijaan tietämys seksitauteihin, etenkin klamydiainfektioon, oli heikkoa lähes kaikilla nuorilla. Klamydiainfektion yhteys 
alentuneeseen hedelmällisyyteen on tunnettu jo kauan, mutta infektion ilmaantuvuus on siitä huolimatta pysynyt korkeana (6).

Ulkomaalaistausteisten nuorten SELI-terveystiedot vaikuttavat oleellisesti heidän kykyynsä vastuulliseen ja turvalliseen seksikäyttäytymiseen sekä kykyyn hakea tarvittaessa tietoa ja apua (4). Osalla ulkomaalaistaustaisista nuorista seksikäyttäytyminen on ollut riskialtista ja johtanut muun muassa ei toivottuihin raskauksiin (39). Runsas päihteiden käyttö, joka on yhteydessä seksuaaliseen riskikäyttäytymiseen (40), on ollut ulkomaalaistaustaustaisilla nuorilla suomalaistaustaisia yleisempää (10). Toisaalta somali- ja kurditaustaisten nuorten sekä vakava seurustelu (14) että päihteiden käyttö (41) ovat selvästi harvinaisempia kuin suomalaistaustaisilla nuorilla.

Seksuaalikasvatuksen tavoitteena on edistää SELI-terveyttä ja -tietämystä $(32,33)$. Seksuaalikasvatus on elämän pituinen prosessi, johon sisältyy siihen liittyvien tietojen, taitojen ja arvojen hankkiminen seksuaalisista suhteista, identiteetistä ja intimiteetistä (43). Sen tulee perustua sukupuolten ja yksilöiden väliseen tasa-arvoon, itsemääräämisoikeuteen ja erilaisuuden hyväksymiseen ja kunnioittamiseen. Seksuaalikasvatuksen tulee luoda pohjaa hyvälle itsetunnolle ja ihmissuhteille sekä toisten ihmisten kunnioittamiselle ja seksuaalisuuden moninaisuuden, sukupuoli-identiteetin ja sukupuoliroolien tiedostamiselle.

Koulujen seksuaalikasvatuksessa on tärkeää huomioida myös yhteiskunnan monikulttuuristuminen $(11,32,33)$ ja ottaa huomioon opetuksen sisällön toteuttamisessa ulkomaalaistaustaisten lasten ja nuorten erilaiset lähtökohdat $(22,44)$. Ulkomaalaistaustaisten SELI tietämystä tutkittaessa on todettu, että SELI terveyskäsitykseen ja toisaalta tietoon vaikuttavat vahvimmin henkilön kulttuurinen ja uskonnollinen tausta (45-47) jopa niin, että se heikentää nuoren SELI-tietämyksen kehittymistä vieraaseen ympäristöön muutettaessa (48). Kingorin ym. amerikkalaisessa tutkimuksessa todettiin, että nuorten ulkomaalaistaustaisten SELI-tietämys on parempi kuin heidän vanhemmillaan ja nuoret etsivät tietoa kodin ulkopuolelta, esimerkiksi terveydenhoitoalan ammattilaisilta (48). Samankaltaisia tuloksia on saatu australialaisessa tutkimuksessa, jossa todettiin sukupolvien välisten erojen olevan nähtävissä SELI-terveyskäsityksissä ja asenteissa (49). Myös tässä tutkimuksessa korostettiin varhaisen koulutuksen merkitystä nuorten tietotason kehittäjänä ja SELI- terveyttä parantavana tekijänä. Siellä, missä nuoret ovat saaneet seksuaalikasvatusta Suomen tavoin, nuorten SELI-tietämys on parantunut (50).

Tärkeä merkitys on myös niin sanotulla epävirallisella seksuaalikasvatuksella, jota antavat muun muassa vanhemmat $(5,51)$. Seksuaalikasvatusta on Suomessa annettu osana terveystiedon opetusta jo niin pitkään, että suomalaistaustaisten nuorten vanhemmat ovat jo itse saaneet seksuaalikasvatusta koulussa ja siten heillä voi olla paremmat lähtökohdat antaa epävirallista seksuaalikasvatusta kuin monilla ulkomaalaistaustaisilla vanhemmilla. Muun muassa vanhempien oma tietämättömyys, sosiokulttuuriset uskomukset, uskonnollisuus ja sukupuolten epätasa-arvo voivat vaikuttaa ulkomaalaistaustaisten vanhempien valmiuksiin keskustella nuorten kanssa SELI-asioista (52). Tämä on hyvä huomioida myös kodin ja koulun yhteistyössä.

Kielivaikeudet, vuorovaikutuksen ongelmat, tiedon saamisen vaikeudet, leimautumisen pelko ja SELI-asioiden tabuna pitäminen voivat estää tai vaikeuttaa SELI-terveyspalveluihin hakeutumista tai oikean palvelun löytämistä $(9,22,53,54$ 56). Palvelun tarjoajan puolelta taas ulkomaalaistaustaisten SELI-terveydentilaan vaikuttaa terveydenhoitojärjestelmän valmius vastata erilaisista taustoista tulevien ihmisten tarpeisiin.

Kansainvälisen vertailun mukaan koulun yhteydessä olevat ja nuorille tarkoitetut SELIterveyspalvelut näyttävät parhaiten edistävän nuorten SELI-terveyttä $(57,58)$. Ulkomaalaistaustaisten nuorten SELI-terveystietämyksen tason parantamisessa ja tietämyseron kaventamisessa koulu- ja opiskeluterveydenhuollon palvelut ovat erityisen tärkeässä asemassa avun tarjoajana ja tiedon jakajana. Suomalaisnuorten mielestä etenkin terveydenhoitajan, lääkärin, psykologin ja kuraattorin palvelujen saatavuus on parantunut (7). Toisaalta taas ensimmäisen polven maahanmuuttajanuoret arvioivat kouluterveydenhoitajan vastaanotolle pääsyn vaikeammaksi kuin muut nuoret (10). Huomiota tulee kiinnittää siihen, miten palvelut tavoittavat ulkomaalaistaustaiset nuoret ja miten he osaa- 
vat hakeutua palveluun. Ulkomaalaistaustainen nuori ei aina tiedä olemassa olevista palveluista eikä tunne palvelujärjestelmää.

Ammattitaitoisten tulkkaus- ja käännöspalveluiden lisäksi (22) hoitohenkilökunnan asenteet ja tieto sekä esimerkiksi Suomessa ulkomaalaistausten henkilöiden saatavilla oleva tieto ovat olennaisia tekijöitä terveyspalvelujen laadun ja saavutettavuuden tekijöiden ohella (8). Palvelun käyttöä voi tukea esimerkiksi palveluista tiedottamalla sekä varmistamalla mahdollisuuden hakeutua niihin koulupäivän ajankohdasta tai opetuspaikan sijainnista riippumatta (15).

Ulkomaalaistaustainen nuori ei välttämättä saa palvelujärjestelmästä tarpeenmukaista tukea tai palvelua. Nuori voi tietää palveluista ja on motivoitunut niitä hakemaan, mutta palvelujärjestelmässä ei riittävästi tunnisteta erityistarpeita tai tarpeet tulkitaan tai selitetään väärin (53). Huomiota tulisi kiinnittää siihen, osaako terveydenhuollon henkilöstö huomioida ulkomaalaistaustaisen nuoren mahdolliset erityistarpeet maahanmuutto- ja kulttuuritaustaan liittyen kielikysymyksen lisäksi. Saatavilla tulisi olla nuoren omalle kielelle käännettyä materiaalia ja tietopaketteja. Myös ulkomaalaistaustaiselle nuorelle tulee olla saatavilla matalan kynnyksen apua ja tietoa.

Suomessa on yhä enemmän monikulttuurisia ja keskenään hyvin erilaisista kulttuureista lähtöisin olevia, perheitä perustavia nuoria, jotka itse tai joiden toinen vanhempi tai molemmat van- hemmat ovat muuttaneet ulkomailta Suomeen. Jotta palveluja ja koulutusta voidaan suunnata oikeille kohderyhmille ja oikeassa muodossa, tulevaisuudessa tarvitaan lisää syventävää tutkimusta eri tekijöiden vaikutuksesta ulkomaalaistaustaisten nuorten SELI-tietämykseen, tietämyksen eroista eri kulttuureissa ja tietämyksen yhteydestä ulkomaalaistaustaisten nuorten terveyteen ja hyvinvointiin.

\section{KIRJOITTAJIEN KONTRIBUUTIOT}

RK ideoi ja suunnitteli tutkimusaiheen yhdessä muiden kirjoittajien kanssa, kirjoitti ensimmäisen version artikkelista ja viimeisteli artikkelin muiden kommenttien perusteella. JS osallistui tutkimusaiheen ideoimiseen, analysoi aineiston ja osallistui artikkelin kirjoittamiseen ja kommentointiin. AM osallistui tutkimusaiheen ideoimiseen, tutkittavan aineiston luokitteluun ja artikkelin kirjoittamiseen ja kommentointiin. HMS ideoi tutkimusaiheen, tutkittavan aineiston luokittelun ja artikkelin rakenteen, osallistui artikkelin kirjoittamiseen ja kommentointiin.

\section{LYHENTEET}

Seksuaali- ja lisääntymisterveys = SELI-terveys Seksuaali- ja lisääntymisterveyspalvelut = SELIpalvelut

Sosiaali- ja terveysministeriö $=$ STM

Terveyden ja hyvinvoinnin laitos $=\mathrm{THL}$

World Health Organization $=$ WHO

Klemetti, R.Seppänen, J., Matikka,A.Surcel,H-M. Knowledge of sexual and reproductive health of immigrant youth in School Health Promotion Study 2015. Sosiaalilääketieteellinen aikakauslehti - Journal of Social Medicine 2017:54: 209-225

Sexual and reproductive health is an important part of welfare in life. Knowing the special needs of immigrant youth's in this matter is a requirement in order to help forward and produce services equally despite of cultural and linguistic background. The purpose of this study was to find out the level of knowledge of sexual and reproductive health of immigrant youth and to compare it to that of native youth as well as to study background factors related to their knowledge. Data are based on a national School Health Promotion study which was carried out year 2015. The survey had 120400 respondents in total and $11 \%$ of these were considered to have immigrant background according to their own or parents' country of birth. Knowledge of sexual and reproductive health varied by gender, education level and type of foreign background. Youth from multicultural or immigrant families have generally a lower sexual and reproductive awareness than native youth. Short period in Finland and weak language skills explain this only partially since also second generation immigrants have lower awareness in sexual and reproductive health and welfare when compared to native population. Foreign background is clearly connected to knowledge of sexual and reproductive health of youth and this connection is present despite 
of educational level. Good knowledge of sexual and reproductive health was lower in every group than needed to be able to improve health and welfare of youth.

\section{LÄHTEET}

(1) Suomen virallinen tilasto (SVT): Väestörakenne [verkkojulkaisu]. ISSN=1797-5379. Helsinki: Tilastokeskus [viitattu: 11.12.2016]. Saantitapa: http://www.stat.fi/til/vaerak/index.html.

(2) Tilastokeskus. Ulkomaalaistaustaiset. http://www.stat.fi/tup/maahanmuutto/ maahanmuuttajat-vaestossa/ ulkomaalaistaustaiset.html

(3) Suomen virallinen tilasto (SVT). Tilastoraportti 17/2016, 19.10.2016. Raskaudenkeskeytykset. THL

(4) Nurmeksela S. Suomessa asuvien yläkouluikäisten maahanmuuttajanuorten seksuaaliterveystiedot. Jyväskylän yliopisto. Terveystieteiden laitos. Pro gradu-tutkielma, 2011.

(5) Klemetti R, Raussi-Lehto E. (toim.) Edistä, ehkäise, vaikuta - Seksuaali- ja lisääntymisterveyden toimintaohjelma 2014-2020. Opas 33/2014. THL. Tampere: Juvenes Print - Suomen Yliopistopaino Oy; 2014. Luettavissa: http://urn.fi/ URN:ISBN:978-952-302-174-7.

(6) Jaakola S, Lyytikäinen O, Rimhanen-Finne R ym. Tartuntataudit Suomessa 2015. Raportti 10/2016. Helsinki: THL; 2016.

(7) Luopa P, Lommi A, Kinnunen T ym. Nuorten hyvinvointi Suomessa 2000-luvulla. Kouluterveyskysely 2000-2009. Raportti 20/2010. Helsinki: THL; 2010.

(8) Väestöliitto: Maahanmuuttajien seksuaalija lisääntymisterveyden edistäminen. Toimintasuunnitelma. Työryhmä: Apter D, Eskola M-S, Kettu N ym., Helsinki: Väestöliitto 2009.

(9) Sainola- Rodriguez K. Transnationaalinen osaaminen - uusi terveydenhuoltohenkilöstön osaamisvaatimus. Kuopion yliopisto. Yhteiskunnallinen tiedekunta. Väitöskirja. 2009.

(10) Matikka A, Luopa P, Kivimäki H ym. Maahanmuuttajataustaisten 8.- ja 9.-luokkalaisten hyvinvointi. Kouluterveyskysely 2013. Raportti 26/2014. Helsinki: THL; 2014.

(11) Sosiaali- ja terveysministeriö. 2007. Seksuaali- ja lisääntymisterveyden edistäminen. Toimintaohjelma 2007-2011. Helsinki: Sosiaali- ja terveysministeriö. http://www.stm.fi/c/document_library/ get_file?folderId=28707\& name=DLFE-3584. pdf\&title=Seksuaali_ja_lisaantymisterveyden_ edistaminen_fi.pdf.

(12) Castaneda AE, Rask S, Koponen P ym. (toim.) Maahanmuuttajien terveys ja hyvinvointi. Tutkimus venäläis-, somalialais- ja
Keywords: Immigrants, foreign background, sexual and reproductive health, awareness, youth

kurditaustaisista Suomessa. THL Raportti 61/2012. Tampere: Juvenes Print - Suomen Yliopistopaino Oy; 2012.

(13) Castaneda AE, Larja L, Nieminen T ym. Ulkomaalaisten psyykkinen hyvinvointi, turvallisuus ja osallisuus. Työpaperi 15/2014, THL, 2014.

(14) Malin M. Seurustelu ja seksuaalisuus. Teoksessa: Wikström K, Haikkola L, Laatikainen T. (toim.) Maahanmuuttajataustaisten nuorten terveys ja hyvinvointi. Tutkimus pääkaupunkiseudun somali- ja kurditaustaisista nuorista. Työpaperi 17/2014. THL, 2014: 59-61. Luettavissa: https:// urn.fi/URN:ISBN:978-952-302-212-6.

(15) Luopa P, Kivimäki H, Matikka A ym. Nuorten hyvinvointi Suomessa 2000-2013. Kouluterveyskyselyn tulokset. Raportti 25/2014. Helsinki: THL; 2014. Luettavissa: http://urn.fi/ URN:ISBN:978-952-302-280-5.

(16) Opetushallitus. Perusopetuksen opetussuunnitelman perusteet 2004. Helsinki: Opetushallitus; 2004. Luettavissa: http://www. oph.fi/download/139848_pops_web.pdf.

(17) Isola S-M, Ali-Sisto M-I. Seksuaali- ja lisääntymisterveys ja sosioekonomiset taustat. Oulun ammattikorkeakoulu. Hoitotyön koulutusohjelma. Opinnäytetyö. 2014. Luettavissa: http://urn.fi/ URN:NBN:fi:amk-201405086646

(18) Coleman LM, Testa A. Sexual health knowledge, attitudes and behaviours: variations among a religiously diverse sample of young people in London, UK. Ethn Health 2008;13(1):55-72. https://doi.org/10.1080/13557850701803163

(19) Koivurova A, Saario E. Maahanmuuttajataustaisten nuorten seksuaali- ja lisääntymisterveystietämys. Opinnäytetyö. Syksy 2014. Hoitotyön koulutusohjelma. Oulun ammattikorkeakoulu,2014.

(20) Virtala A, Vilska S, Huttunen T ym. Childbearing, the desire to have children, and awareness about the impact of age on female fertility among Finnish university students. Eur J Contracept Reprod Health Care 2011; 16:108115. doi: 10.3109/13625187.2011.553295. https://doi.org/10.3109/13625187.2011.553295

(21) Nipuli S, Hemminki E, Rämö A ym. Finnish university students' knowledge of the health impacts of postponing childbearing, Finland 2011. International Journal of Health Promotion and Education, 2017. http://dx.doi. org/10.1080/14635240.2016.1250659. https://doi.org/10.1080/14635240.2016.1250 659 
(22) Rademakers J, Mouthaan I, de Neef M. Diversity in sexual health: problems and dilemmas. Eur J Contracept Reprod Health Care 2005;10(4):207-11. https://doi.org/10.1080/13625180500279847

(23) Kilpi-Jakonen E. Does Finnish educational equality extend to children of immigrants?

Examining national origin, gender and the relative importance of parental resources. Nordic Journal of Migrant Research 2012; 2(2): 167-181. DOI: 10.2478/v10202-011-0039-4. https://doi.org/10.2478/v10202-011-0039-4

(24) Kågesten A, Blum RW. Characteristics of youth who report early sexual experiences in Sweden. Arch Sex Behav 2015;44(3):679-694. https://doi.org/10.1007/s10508-015-0499-z

(25) Simkhada P, Van TE, Regmi PR, Bhatta P. Sexual health knowledge, sexual relationships and condom use among male trekking guides in Nepal: a qualitative study. Culture, Health and Sexuality 2010; 12: 45-58. https://doi.org/10.1080/13691050903266080

(26) Kraeger DA, Staff J. The sexual double standard and adolescent peer acceptance. Social Psychol Q 2009;72:143-164.

https://doi.org/10.1177/019027250907200205

(27) Hyvärinen S. Erola J. Perhetaustan vaikutus toisen polven maahanmuuttajien kouluttautumiseen Suomessa. Mahdollisuuksien tasa-arvo stressitestissä? Yhteiskuntapolitiikka 2011; 5:644-657.

(28) Leinonen E, Säävälä M, Alitolppa-Niitamo A ym. Pääasiallinen toiminta, koulumenestys, kouluviihtyvyys ja vanhempien suhtautuminen koulunkäyntiin. Teoksessa: Wikström K, Haikkola L, Laatikainen T. (toim.) Maahanmuuttajataustaisten nuorten terveys ja hyvinvointi. Tutkimus pääkaupunkiseudun somali- ja kurditaustaisista nuorista. Työpaperi 17/2014. THL, 2014: 59-61. Luettavissa: https:// urn.fi/URN:ISBN:978-952-302-212-6

(29) Sosiaali- ja terveysministeriön asetus rokotuksista ja tartuntatautien raskaudenaikaisesta seulonnasta annetun sosiaali- ja terveysministeriön asetuksen liitteen muuttamisesta. 6.6. 2013.STM 410/2013.

(30) Terveyden ja hyvinvoinnin laitos, 2014. http:// tyttojenjuttu.fi/. Viitattu 24.1.2017.

(31) Opetushallitus, 2014. Perusopetuksen tuntijako, 2014. http://www.oph.fi/download/46678_pops_ liite4.pdf

(32) Opetushallitus, 2015. Lukion opetussuunnitelman perusteet. Määräykset ja ohjeet 2015:48. http://www.oph.fi/ download/172124_lukion_opetussuunnitelman_ perusteet_2015.pdf

(33) Opetushallitus, 2014. Perusopetuksen opetussuunnitelman perusteet. Määräykset ja ohjeet 2014:96.M

(34) Opetushallitus, 2012. Ammatillisten perustutkintojen toimeenpano. Oppaat ja käsikirjat 2012: 10. Ammatillisen http://www.
oph.fi/download/142550_Ammatillisten_ perustutkintojen_perusteiden_toimeenpano.pdf

(35) Kaikkonen R, Mäki P, Hakulinen-Viitanen T ym. (toim.) Lasten ja lapsiperheiden terveys- ja hyvinvointierot. Raportti 16/2012. Helsinki: THL; 2012.

(36) Kilpi E. The education of children of immigrants in Finland. DPhil. University of Oxford.2010. https://ora.ox.ac.uk/objects/ uuid:9ae6dfc5-bda6-4d6f-8780-c97abab350e9

(37) Kilpi-Jakonen E. Continuation to upper secondary education in Finland: Children of immigrants and the majority compared. Acta Sociologica 2011;54(1):77-106. https://doi.org/10.1177/0001699310392604

(38) Yu J. Young people of Chinese origin in western countries: a systematic review of their sexual attitudes and behaviour.Health Soc Care Community 2010;18(2):117-128. https://doi.org/10.1111/j.13652524.2009.00906.x

(39) Malin M, Gissler M. Induced abortions among immigrant women in Finland. Finnish Journal of Ethnicity and Migration 2008;3(1):2-12.

(40) Nikula M. Young Men's Sexual Behaviour in Finland and Estonia: Opportunities for Preventation of Sexually Transmitted Infections. Helsinki: Terveyden ja hyvinvoinnin laitos; 2009.

(41) Haikkola L, Le T. Tupakointi ja muiden päihteiden käyttö. Teoksessa: Wikström K, Haikkola L, Laatikainen T. (toim.) Maahanmuuttajataustaisten nuorten terveys ja hyvinvointi. Tutkimus pääkaupunkiseudun somali- ja kurditaustaisista nuorista. Työpaperi 17/2014. THL, 2014: 55-59. Luettavissa: https:// urn.fi/URN:ISBN:978-952-302-212-6.

(42) World Health Organization.

Seksuaalikasvatuksen Standardit Euroopassa. Suuntaviivat poliittisille päättäjille, opetusja terveydenhoitoalan viranomaisille ja asiantuntijoille. Maailman terveysjärjestön (WHO) Euroopan aluetoimisto ja BZgA. Helsinki: THL; 2010. Luettavissa: https://www. julkari.fi/handle/10024/80220.

(43) Kontula O, Meriläinen O. Koulun seksuaalikasvatus 2000-luvun Suomessa. Väestöntutkimuslaitos. Katsauksia E26/2007. Vantaa: Dark Oy; 2007.

(44) Madkour AS, de Looze M, Ma P ym. Macro-Level Age Norms for the Timing of Sexual Initiation and Adolescents' Early Sexual Initiation in 17 European Countries. J Adolesc Health 2014 Feb 6. pii: S1054-139X(13)00828-8. doi:10.1016/j. jadohealth.2013.12.008. https://doi.org/10.1016/j. jadohealth.2013.12.008

(45) Ussher JM, Perz J, Metusela C ym. Negotiating discurses of shame, secrecy, and silence: migrant refugee women's experiences of sexual embodiment. Arch Sex Behav 2017, Jan 12 doi: 10.007/s10508-016-0898-9. 
(46) Meldrum RM, Liamputtong P, Wollersheim D. Sexual helath knowledge and needs: young Muslim women in Melbourne, Australia. Int J health Serv 2016;46(1):124-40. doi:10.1177/0020731415615313. https://doi.org/10.1177/0020731415615313

(47) Connor JJ, Hunt S, Finsas M, Ciesinski A, Ahmed A, Robinson BB. Sexual health care, sexual bahaviors and functioning, and female genital cutting: perspective from Somali women living in the United States. J Sex Res 2016;53(3):346-59. doi: 10.1080/00224499.2015.1008966. https://doi.org/10.1080/00224499.2015.10089 66

(48) Kingori C, Ice Gh. Hassan Q, Elmi A, Perko E. "If I went to my mom with that information, I'm dead": sexual health knowledge barriers among immigrant and refugee Somali young adults in Ohio. Ethn Health 2016, Nov 28:1-14. doi:10.1 080/13557858.2016.1263285. https://doi.org/10.1080/13557858.2016.12632 85

(49) Dean J, Mitchell M, Stewart D, Debattista J. Intergenerational variation in sexual health attitudes and belifs among Sudanese refugee communities in Australia. Cult Health Sex 2017;19(1):17-31. https://doi.org/10.1080/13691058.2016.11843 16

(50) Thato R, Jenkins RA, Dusitsin N. Effects of the culturally-sensitive comprehensive sex education programme among Thai secondary school students. Journal of Advanced Nursing 2008; 62: 457- 469 .

https://doi.org/10.1111/j.1365-

2648.2008.04609.x

(51) Bildjuschkin K. Seksuaalinen hyvinvointi ja nuori maahanmuuttaja. Kirjassa: Riitta AlaLuhtala, Sirpa Valkama-Hietamäki. (toim.) Maahanmuuttajien seksuaaliterveyden edistäminen. JAMK. Suomen Yliopistopaino Oy - Juvenes Print; 2016:45-52.

(52) Taffa N, Bjune G, Sundby J, Gaustad P, Alestrom A. Prevalence of gonococcal and chlamydial infections and sexual risk behavior among youth in Addis Ababa, Ethiopia. Sexually Transmitted Diseases 2002; 29: 828833.

https://doi.org/10.1097/00007435-20021200000015

(53) Alitolppa-Niitamo A, Moallin M, Novitsky A. 2005. Välittävä perhetyö - kokemuksia ja ajatuksia Väestöliiton Kotipuu-projektista. Teoksessa Alitolppa-Niitamo A, Söderling I, Fågel S. (toim.) Olemme muuttaneet. Näkökulmia maahanmuuttoon, perheiden kotoutumiseen ja ammatillisen työn käytäntöihin. Helsinki: Väestöliitto, 2005, 84-95. http://vaestoliitto.fibin.directo.fi/@
Bin/ 920fed86f031d5c6eac6205607e2ca6e/ 1418233428/application/pdf/490819/

Olemmemuuttaneet.pdf

(54) Linberg C, Lewis SC, Crownover R. Barriers to sexual and reproductive health care: urban male adolescents speak out. Comprehensive Pediatric Nursing 2006; 29: 73-88. https://doi.org/10.1080/01460860600677577

(55) Colombini M, Mayhew SH, Rechel B. Sexual and reproductive health needs and access to services for vulnerable groups in Eastern Europe and Central Asia. United Nations Family Planning Association (UNFPA) 2011.

(56) Kennedy EC, Bulu S, Harris J, Humphreys D, Malverus J, Gray NJ. "Be kind to young people so they feel at home": a qualitative study of adolescents' and service providers' perceptions of youth-friendly sexual and reproductive health services in Vanuatu. BMC Health Services Research 2013; 13:455. https://doi.org/10.1186/1472-6963-13-455

(57) Hosie A. Sexual health policies and trends in Europe. Teoksessa: Burtney E, Duffy M (toim.) Young people and sexual health. Individual, social and policy context. Bristol 2004:60-79. https://doi.org/10.1007/978-1-137-04292-7_4

(58) Ahern NR, Kiehl EM. Adolescent sexual health $\&$ practice - a review of the literature: implications for healthcare providers, educator, and policy makers. Fam Comm Health 2006;29:313. https://doi.org/10.1097/00003727-20061000000008

\section{Reija Klemetti \\ FT, dosentti, Tutkimuspäällikkö \\ Terveyden ja hyvinvoinnin laitos}

\section{Johanna Seppänen}

FT, erikoistutkija

Terveyden ja hyvinvoinnin laitos

\section{AnNi MatikKa}

TtM, tutkija

Terveyden ja hyvinvoinnin laitos

Heljä-Marja Surcel

FT, dosentti, erityisasiantuntija

Terveyden ja hyvinvoinnin laitos 


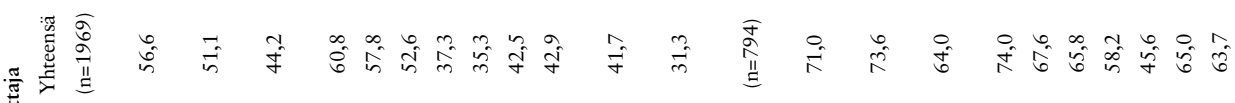

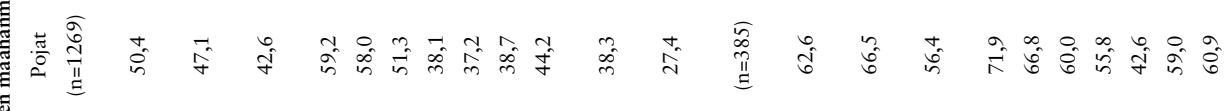
蜜

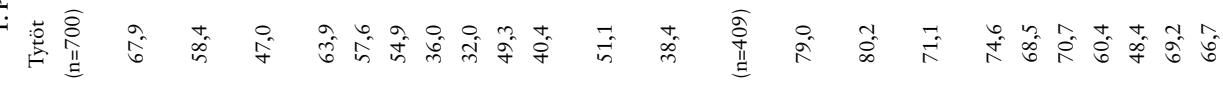

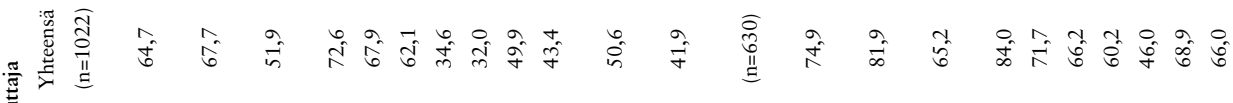

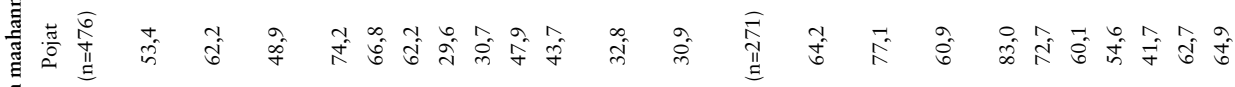

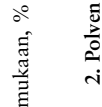

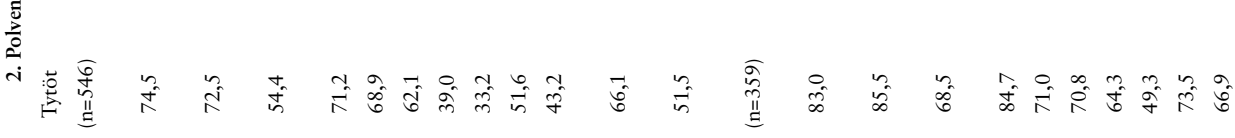

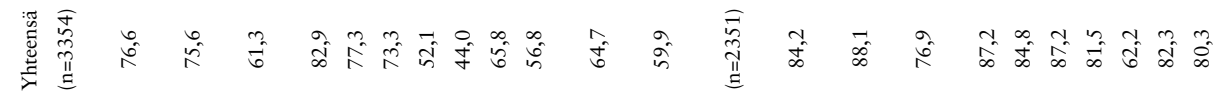

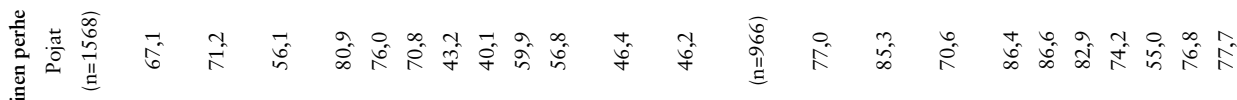

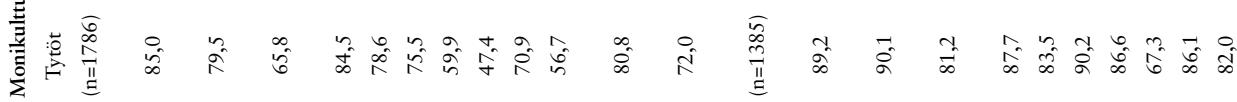

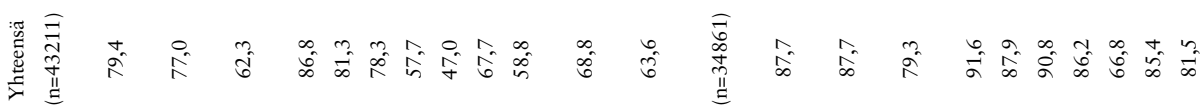

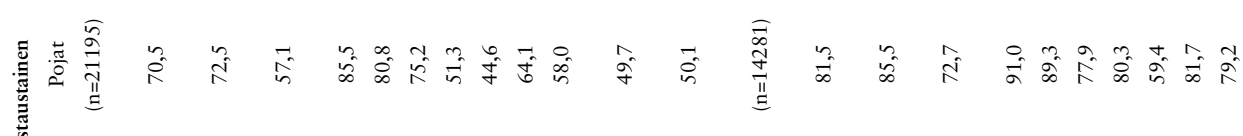

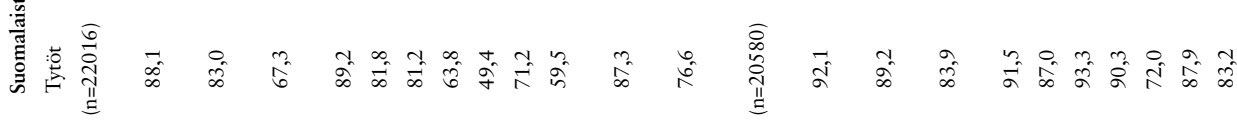
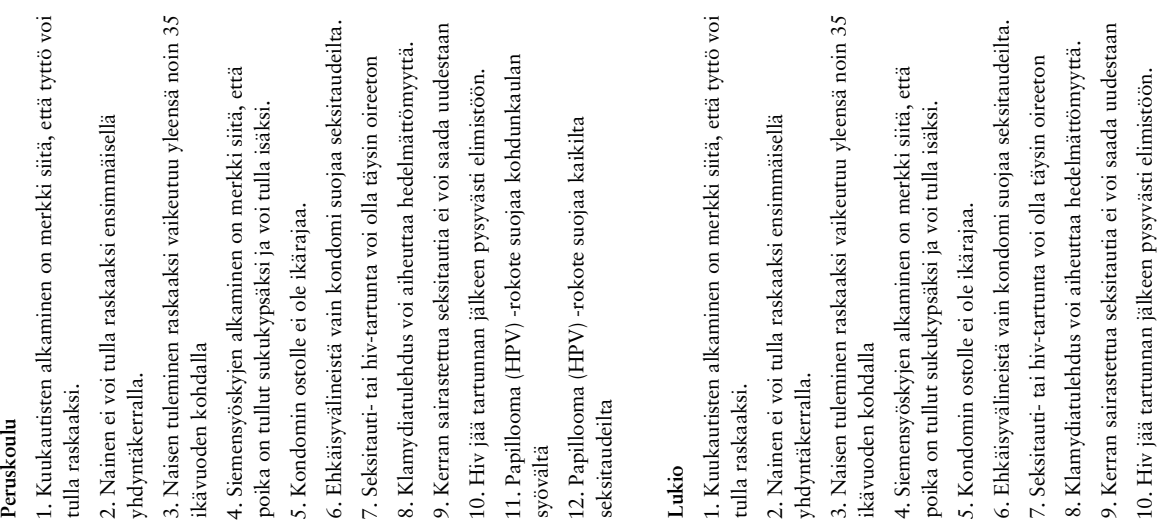


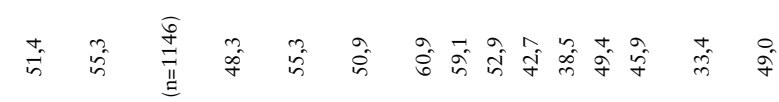

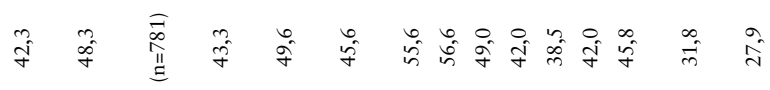

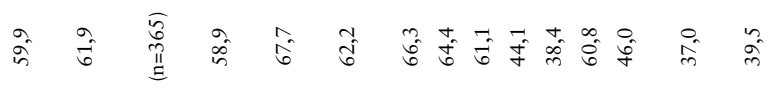

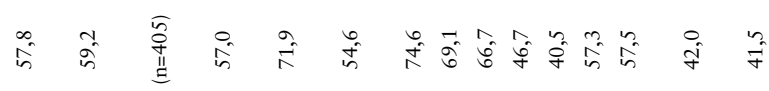

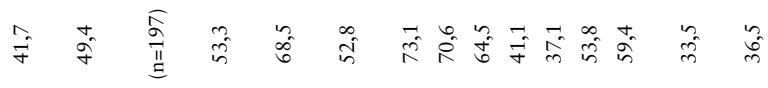

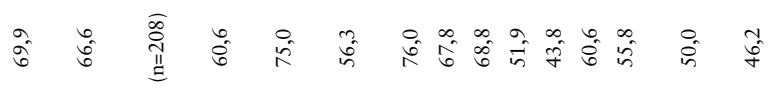

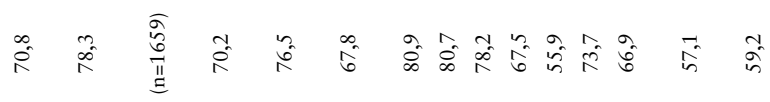

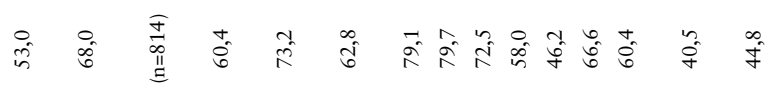

की

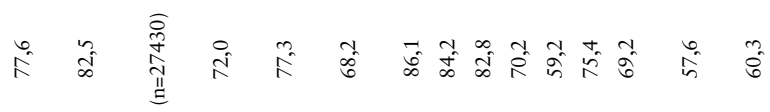

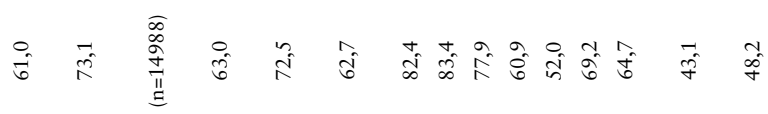

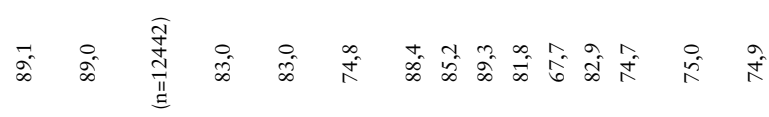

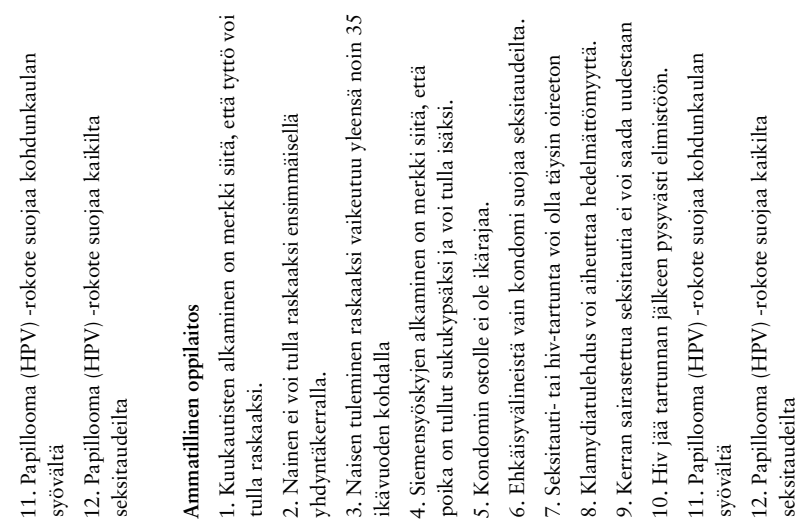

